\title{
Natureza, vida e finalismo nas notas sobre a teleologia e sobre a origem da linguagem de Nietzsche (1868-69)
}

\author{
William Mattioli*
}

Resumo: Este artigo corresponde à segunda de duas partes que perfazem um estudo sobre a questão da teleologia nos apontamentos do jovem Nietzsche entre 1867 e 1869. No seu todo, o trabalho pretende oferecer uma leitura de três conjuntos de notas escritos pelo filósofo nesse período: Zu Schopenhauer, Zur Teleologie e Vom Ursprung der Sprache, com um claro enfoque nas notas sobre a teleologia, de 1868. Meu objetivo é tentar mostrar que, apesar das diversas críticas de Nietzsche à teleologia e de sua aparente adesão (via Lange) ao darwinismo, sua posição é melhor compreendida como um tipo de vitalismo, que é receptivo à ideia de uma intencionalidade inconsciente na natureza, mas que recusa explicitamente a concepção antropomorficamente inflacionada de um designer divino. Nesta segunda parte do estudo, encerro minha análise, iniciada na primeira parte, do conjunto de notas reunidas sob o título Zur Teleologie e as contextualizo no horizonte das teses defendidas por Nietzsche no texto Vom Ursprung der Sprache, escrito cerca de um ano depois.

Palavras-chave: Nietzsche; natureza; teleologia; força vital; inconsciente.

\footnotetext{
* Professor Adjunto do Departamento de Filosofia da Universidade Federal do Rio de Janeiro e membro do Programa de Pós-Graduação em Filosofia da mesma universidade. Correio Eletrônico: william.mattioli@gmail.com.
}

ORCID: https://orcid.org/0000-0003-2894-548X 
Natureza, vida e finalismo nas notas sobre a teleologia e sobre a origem da linguagem de Nietzsche (1868-69)

\section{Introdução}

No trabalho que se segue, levo a cabo minha análise das notas sobre a teleologia do jovem Nietzsche, apresentada, em sua primeira parte, no artigo: "A questão da teleologia nos apontamentos do jovem Nietzsche: Zu Schopenhauer e Zur Teleologie (1867-68)", ${ }^{1}$ publicado nesta revista em 2018. A título de conclusão, insiro esses apontamentos no contexto das notas sobre origem da linguagem, escritas imediatamente depois. Como no primeiro artigo, a interpretação apresentada aqui se baseia em três estratégias de leitura: 1) a indicação de certas ambiguidades do texto, tendo em vista demonstrar que a suposta rejeição da teleologia é na verdade a rejeição de um tipo específico de raciocínio teleológico, a saber, aquele parasitado por concepções teológicas e que fornece a base para a físico-teologia; 2) uma confrontação com as fontes de Nietzsche, em especial Lange e Schopenhauer, tendo em vista elucidar o uso de alguns conceitos e algumas expressões e localizar melhor sua posição no debate; e 3) uma contextualização destas notas no conjunto dos apontamentos do período. Meu intuito é mostrar que a rejeição de qualquer tipo de intencionalidade na natureza vai de encontro às teses defendidas nesses dois outros textos.

\section{Vida, força vital e a desconstrução da unidade do organismo}

As notas sobre a teleologia contêm duas passagens nas quais Nietzsche esboça o que seria o plano da tese de doutoramento que ele pretendia escrever. ${ }^{2}$ A primeira corresponde ao fragmento 62[44]:

1 Cf. Mattioli, 2018a.

2 Essas notas correspondem ao plano para a tese de doutoramento que Nietzsche planejava escrever sobre o conceito de teleologia em Kant, cujo tema central seria "o conceito do orgânico a partir de Kant" (cf. carta ao amigo Paul Deussen do final de abril / início de maio de 1868). As notas para a dissertação se encontram em KGW I/4, pp. 549-578 e correspondem aos fragmentos 62[3] - 62[57] de abril/maio de 1868. Apesar de se tratar de um projeto abandonado

Cad. Nietzsche, Guarulhos/Porto Seguro, v.41, n.3, setembro-dezembro $2020 \mid 127$ 
Cap. I. O conceito de conformidade a fins (como capacidade para a existência)

II. Organismo (o conceito indeterminado de vida, o conceito indeterminado de indivíduo).

III. A suposta impossibilidade de se explicar um organismo mecanicamente (o que significa mecânico?)

IV. A reconhecida ausência de finalidade na natureza em contradição com a conformidade a fins (NF/FP 62[44], KGW I/4.567).

A segunda passagem encontra-se no fragmento 62[49]:

Cap. I. A consideração teleológica é uma consideração segundo formas II. Formas (indivíduos) pertencem à organização humana e são dela derivadas.

III. Força vital (Lebenskraft) $=($ NF/FP 1868 62[49], KGW I/4.573).

O esboço do primeiro plano testemunha, antes de mais nada, a centralidade da tese nietzschiana de que a conformidade a fins deve ser entendida simplesmente como a capacidade de viver (ou a capacidade de existir, de um modo mais geral). ${ }^{3}$ Este tópico resume o que viria a ser o conteúdo do primeiro capítulo da tese de douramento. A ele corresponde parcialmente o primeiro capítulo do segundo plano, que introduz a noção de forma. A afirmação de que a consideração teleológica se refere à capacidade de viver de um organismo determinado tem como contraface a tese de que tal consideração tem por objeto privilegiado a forma a partir da qual um indivíduo orgânico vem a ser e se mantém na existência enquanto ser vivo. "O que vemos da vida é a forma; como a vemos, o

pouco tempo depois (cf. carta ao amigo Erwin Rohde de 03 ou 04 de maio de 1868), essas notas contém indicações importantes de quais eram as questões relevantes para Nietzsche naquele momento (como as questões relativas aos limites da individuação e à relação entre materialismo e teleologia) e do modo como ele articulava diferentes fontes na elaboração de suas respostas a tais questões.

3 Contra Kant, Nietzsche recusa que a conformidade a fins do organismo deva ser remetida a uma causa final que lhe seja externa, de modo que o que nos resta desse conceito é sua referência à capacidade de autorregulação e autoconservação do organismo, isto é, sua capacidade de viver (NF/FP 1868 62[15], KGW I/4.554). 
Natureza, vida e finalismo nas notas sobre a teleologia e sobre a origem da linguagem de Nietzsche (1868-69)

indivíduo. O que se encontra por trás disso é incognoscível" (NF/ FP 62[52], KGW I/4.575). Ou seja, do ponto de vista da representação, a vida só se faz presente enquanto forma, na medida em que se manifesta numa determinada organização cuja estrutura formal é percebida externamente por nós como conforme a fins. Por sua vez, a forma é o que determina o organismo como indivíduo.

Segundo a tese nietzschiana, inspirada em Lange, mas já presente em Schopenhauer (e derivada de Kant), a percepção de formas e, portanto, de indivíduos, é um produto da nossa organização, ou seja, é algo relativo ao nosso mecanismo representacional. Este seria o tópico do segundo capítulo da tese de Nietzsche, tanto no primeiro, quanto no segundo planos. "O organismo é uma forma. Se abstrairmos da forma, trata-se de uma pluralidade" (NF/ FP 62[25], KGW I/4.558)"; "Organismo como produto de nossa organização" (NF/FP 62[26], KGW I/4.558). Guiado pelas referências e pelas fontes citadas por Lange (cf. Lange, 1866, pp. 406s.), Nietzsche encontra respaldo para esta tese também na filosofia da natureza de Goethe e nos resultados das pesquisas empíricas de Virchow. A seguinte passagem da Morphologie de Goethe, extraída de Lange, é citada por Nietzsche num momento crucial das notas: "Todo ser vivo, diz Goethe, não é um indivíduo (kein Einzelnes), mas uma pluralidade: mesmo na medida em que nos aparece como indivíduo (Individuum), ele permanece um conjunto de seres vivos independentes" (NF/FP 62[22], KGW I/4.556). Esse importante momento das notas sobre a teleologia constitui a primeira tentativa de Nietzsche de pensar o organismo como uma pluralidade de forças vitais (cf. Lopes, 2008, p. 146), tese que encontrará sua formulação plena na obra de maturidade sob a insígnia da teoria das vontades de poder.

Voltemo-nos agora a um trecho das notas em que Nietzsche concede que a forma do organismo pode ser explicada mecanicamente: "quando os cientistas naturais afirmam que um organismo pode se originar a partir do acaso, isto é, não segundo causas finais, 
pode-se admiti-lo no que diz respeito à forma. A questão que se coloca, porém, é: o que é a "vida" (NF/FP 62[47], KGW I/4.572). A conclusão desta passagem nos permite entrever em que consiste propriamente seu distanciamento com relação à concepção estritamente darwinista, e isso a partir de uma determinação da natureza daquela pluralidade que constitui o organismo. Com efeito, se é verdade que sua forma pode ser explicada mecanicamente (tese que o afasta de $\mathrm{Kant}^{4}$ e o aproxima do mecanicismo), por outro lado é preciso compreender que o organismo não é apenas forma. Um organismo determinado é uma forma específica entre muitas formas possíveis na qual a vida se manifesta, isto é, uma forma que abriga uma manifestação específica da vida ou força vital; em suma, o organismo é "vida formada (geformtes Leben)" (NF/FP 62[46], KGW I/4.569): ele é vida mais forma. Aquilo que se manifesta numa determinada forma é, abstraindo-se desta última, uma multiplicidade vital atravessada por um devir constante: "o organismo é uma forma. Se abstrairmos da forma, ele é uma pluralidade" (NF/FP 62[25], KGW I/4.558); mais à frente, lemos: “O que nós retemos de um ser vivo não é nada mais do que formas. O que vem a ser eternamente é a vida; [...] todas as formas podem ser descartadas, mas a vida!" (NF/FP 62[46], KGW I/4.570).

Há um importante trecho em Lange que serve como ponto de partida para essas reflexões. Nele, o organismo é definido como forma mais matéria (Stoff): "se atentarmos à forma de uma coisa, esta é uma unidade; se abstrairmos da forma, ela é uma pluralidade ou matéria (Stoff)" (Lange, 1866, p. 407). Lange fala aqui em "coisa", e não exatamente em "organismo", mas o contexto não deixa dúvidas quanto ao ponto central da discussão em questão: o indivíduo orgânico. À luz do modelo darwinista (concebido como um modelo

4. Cf. Crítica da faculdade de julgar §64: "Para compreender que uma coisa somente seja possível como fim, isto é, que a causalidade de sua origem não deva ser buscada no mecanismo da natureza, mas sim em uma causa cuja capacidade de atuar é determinada por conceitos, é necessário que a sua forma não seja possível por meras leis naturais, isto é, leis que só podemos conhecer por meio do entendimento aplicado a objetos dos sentidos [grifos W.M.]" (Kant, 2016, p. 265). 
Natureza, vida e finalismo nas notas sobre a teleologia e sobre a origem da linguagem de Nietzsche (1868-69)

fundamentalmente causal e mecanicista), a ideia de que o organismo é um composto de matéria mais forma se apresenta como tese de base de uma concepção em grande medida reducionista, em que o surgimento da forma é entendido como resultado material de uma sequência de acasos favoráveis na série da causalidade mecânica. $\mathrm{E}$ isso porque, se é verdade que a forma é aquilo que perfaz a essência propriamente dita do indivíduo, ela, contudo, deriva, "por necessidade natural, das qualidades da matéria (Stoff)." (Lange, 1866, p. 407) E aqui Lange realiza uma interessante inversão, reconduzindo mais uma vez as qualidades da matéria à forma: "essas qualidades, porém, vistas de perto, são por sua vez igualmente formas, que se associam para produzir formas superiores." (Lange, 1866, p. 407) A forma superior, nesse caso, é o indivíduo orgânico que, contendo em si uma pluralidade de indivíduos viventes, contém ao mesmo tempo uma pluralidade de formas. E uma vez que a forma é o "verdadeiro núcleo da força", o organismo seria também um complexo constituído por uma pluralidade de forças .

Nietzsche, por sua vez, em sua tentativa de compreender a constituição do organismo, abre mão da noção de "matéria", presente no trecho de Lange e reconduzida por este, primeiramente, a formas mais elementares e, em seguida, a forças; Nietzsche substitui essa noção pela noção de "vida". Notemos que no fragmento 62[25], retirado diretamente de Lange, Nietzsche caracteriza o organismo, uma vez que se abstraia de sua forma, como uma pluralidade; mas ele exclui o termo complementar presente em Lange: a matéria (Stoff). Ora, este é justamente o termo que, no interior da explicação mecanicista, determina a natureza daquela pluralidade. Como vimos nas outras passagens citadas acima, Nietzsche determina então essa pluralidade não em termos de "matéria", mas sim em termos de "vida", de modo que a fórmula: organismo = forma + matéria se torna em Nietzsche: organismo = forma + vida; ou: organismo é "vida formada" (NF/FP 62[46], KGW I/4.569). 
Concebida como multiplicidade produtiva em constante devir, a vida aparece como o elemento mais fundamental e originário daquela dimensão pré-individual, anterior à modalidade de individuação própria às operações do intelecto, que estrutura o encadeamento dos fenômenos segundo o princípio da causalidade. Nesse sentido, a vida escapa à explicação mecânica, passando a ocupar uma dimensão que, cum grano salis, é análoga àquela ocupada pela vontade no sistema de Schopenhauer, como determinação de uma interioridade irredutível do fenômeno. Enquanto pluralidade, porém, ela aponta também para uma recusa por parte de Nietzsche da tese schopenhaueriana da unidade metafísica da vontade (já apresentada nos apontamentos de Leipzig e que também configurará um dos momentos centrais de sua crítica madura ao autor do Mundo). A tentativa de Schopenhauer de definir o estatuto metafísico da vontade a partir do predicado da unidade é rejeitada por Nietzsche com base, sobretudo, nas passagens de Lange nas quais ele discute a questão acerca da natureza do indivíduo orgânico e da oposição entre unidade e pluralidade. Segundo Alberto Toscano (2001, p. 49), uma dessas passagens parece ter sido o que forneceu a Nietzsche a inspiração fundamental para o desenvolvimento do seu plano de tese sobre a teleologia, na medida em que ela aparece como um ponto de convergência para suas reflexões acerca das limitações teóricas do materialismo e dos limites da individuação. ${ }^{5}$

Nesse trecho de Lange, há duas coisas que devem ser destacadas: 1) a constatação dos limites explicativos do materialismo no tocante à oposição entre unidade e pluralidade e 2) a crítica à concepção dogmática da matéria. Ademais, há ali uma importante sugestão antikantiana: a ideia de que a relativização do conceito de unidade torna possível a consistência da visão científica. Essa ideia está associada à tentativa de suprimir os limites estabelecidos por Kant entre os modelos explicativos que têm por objeto,

5 Cf. Lange, 1866, pp. 405s. O trecho em questão de Lange está traduzido para o português no excelente estudo de Lopes (2008, p. 146), ao qual eu remeto por razão de economia. 
Natureza, vida e finalismo nas notas sobre a teleologia e sobre a origem da linguagem de Nietzsche (1868-69)

por um lado, os indivíduos orgânicos e, por outro, os fenômenos inorgânicos. Com efeito, a consistência da visão científica, tal como entendida por Lange nesse contexto, depende da sua capacidade de explicar a formação dos organismos sem apelo a princípios teleológicos. Ora, o que nos leva a pensar em fins e conformidade a fins são as unidades discretas dos indivíduos orgânicos. Como nos diz Nietzsche, inspirado em Lange, "não postulamos causas finais na natureza inorgânica, pois aqui não percebemos indivíduos, mas apenas forças" (NF/FP 62[31], KGW I/4.561). Nesse sentido, o movimento teórico de dissolução do indivíduo em uma multiplicidade tem por objetivo equacionar natureza orgânica e natureza inorgânica. Uma vez que a unidade do organismo é ilusória e podemos reduzi-la a uma multiplicidade de forças, podemos abordar o organismo com base nos mesmos métodos teóricos (científicos) dos quais lançamos mão para compreender a natureza inorgânica. A dissolução do conceito de indivíduo implica na dissolução do conceito de "totalidade", do qual depende nossa ideia de "fim", tal como pensada na terceira Crítica.

O conceito de totalidade, porém, é obra nossa. Aqui se encontra a fonte da representação do fim. $\mathrm{O}$ conceito de totalidade não está nas coisas, mas sim em nós.

Essas unidades que chamamos organismos são, por sua vez, multiplicidades.

Na realidade não há indivíduos, antes, indivíduos e organismos não são senão abstrações.

Projetamos posteriormente a ideia de fim nas unidades produzidas por nós mesmos (NF/FP 62[28], KGW I/4.560).

Essa passagem retoma a tese apresentada na citação de Goethe sobre o caráter múltiplo dos organismos, localizada, na obra de Lange, na sequência do trecho sobre a essência do indivíduo orgânico. É ali também que se encontra a menção aos experimentos de Virchow, que apontam na direção de uma compreensão da unidade do organismo em analogia com a unidade social de uma comunida- 
de, ao mesmo tempo em que o autor sublinha o caráter imanente e interno do fim que organiza essa unidade: "O indivíduo é, segundo sua explicação, 'uma comunidade unitária, na qual todas as partes trabalham em conjunto para um fim semelhante" (Lange, 1866, p. 407). Como veremos mais à frente, essa ideia de um "trabalho conjunto", orientado por um fim interno ao organismo, será retomada por Nietzsche ao final das notas.

Dentro desse contexto, a tese do caráter relativo do nosso conceito de unidade torna possível recolocar a pergunta acerca do fundamento pré-individual do domínio da representação, supostamente resolvida por Schopenhauer mediante a oposição metafisicamente estilizada ${ }^{6}$ entre o princípio de individuação como determinante do mundo multifacetado da representação, por um lado, e a individualidade una, suprema e absoluta da vontade, por outro. Como observa Toscano (2001, p. 51), nessa nova concepção, o conceito de unidade parece ser banido da dimensão pré-individual, abrindo caminho para o estabelecimento de uma prioridade ontológica da multiplicidade. Com isso, o cenário schopenhaueriano é invertido. A relativização da unidade tem como resultado uma proliferação infinita da multiplicidade.

No mesmo sentido da leitura de Toscano, Lopes sugere que Nietzsche, em suas reflexões sobre a dimensão pré-individual, ou seja, "sobre aquilo que antecede a constituição pelo entendimento do mundo como representação", está atento em não reproduzir os paradoxos schopenhauerianos (Lopes, 2008, p. 147). Ora, de acordo com o que vimos na primeira parte deste estudo, ${ }^{7}$ uma solução que não reproduza esses paradoxos deve ter em vista pelo menos dois pontos: 1) a ilegitimidade da atribuição do predicado da unidade à vontade e 2) os problemas relativos à origem do intelecto e da representação. Além disso, a perspectiva crítica herdada de Lange permanece como o horizonte contra o qual devemos confron-

6 Cf. Lopes, 2008, p. 145.

7 Cf. Mattioli, 2018a, pp. 82-93. 
Natureza, vida e finalismo nas notas sobre a teleologia e sobre a origem da linguagem de Nietzsche (1868-69)

tar nossas soluções, tendo sempre em vista que a realidade empírica é, de maneira quase incontornável, um produto antropomórfico. Contudo, seria possível abordar o fenômeno segundo seus diversos graus de determinação, caminhando de uma realidade constituída e determinada de maneira grosseiramente antropomórfica a um nível ou dimensão mais profunda do fenômeno e, consequentemente, mais indeterminada. Nesse sentido, o passo dado por Nietzsche tendo em vista uma superação das aporias da metafísica da vontade consiste em identificar a dimensão pré-individual com o âmbito do devir e da multiplicidade vital (Lopes, 2008, p. 148). O conceito de vida entra em cena aqui como um operador teórico fundamental que se refere ao domínio da produção material ou ontogênese. Com isso, a vida será remetida àquela dimensão que antecede a modalidade de individuação que emerge das operações do intelecto. Enquanto tal, ela deve ser entendida como uma multiplicidade vital em constante devir, irredutível ao modelo mecânico. É isso que, ao meu ver, está por trás do tópico correspondente ao que seria o terceiro capítulo de sua tese, apresentado no fragmento 62[49] (KGW I/4.573) e intitulado "força vital" (Lebenskraft). ${ }^{8}$

Nossos conceitos de finalidade, segundo a noção kantiana de conformidade a fins, dizem respeito somente às formas nas quais a vida se manifesta, àquelas formas cuja apreensão por nossas faculdades cognitivas é acompanhada por um sentimento de harmonia. A essas formas subjaz um devir incessante, com relação ao qual tais conceitos se tornam vazios.

O que nós retemos de um ser vivo não é nada mais do que formas. O que vem a ser eternamente é a vida; através da natureza de nosso intelecto capturamos formas: nosso intelecto é demasiado obtuso para perceber a metamorfose contínua; aquilo que lhe é cognoscível ele chama de forma. De fato não existe nenhuma forma, pois em cada ponto tem lugar uma infinidade. Cada unidade concebida (ponto) descreve uma linha. Similar ao conceito de forma é o conceito de indivíduo. Organismos são chamados de unidades, centros de finalidade. Mas unidades só existem para nosso

8 Sobre o conceito de Lebenskraft (força vital), cf. o excurso ao final deste artigo.

Cad. Nietzsche, Guarulhos/Porto Seguro, v.41, n.3, setembro-dezembro 2020 |135 
intelecto. Cada indivíduo tem em si uma infinidade de indivíduos viventes (NF/FP 1868 62[46], KGW I/4.570. Trad. Lopes 2008, p. 151).

Nos apontamentos de Leipzig, Nietzsche acusava Schopenhauer de não ter reconhecido o caráter obscuro da região onde cessa a individuação. Essa seria uma das razões que teriam conduzido o autor do Mundo a paradoxos insolúveis. O pensamento da representação é aqui confrontado com seus limites, o problema da vida, que se apresenta como o verdadeiro enigma. Os conceitos de finalidade apresentados por Kant na terceira Crítica não são capazes de iluminar nossa compreensão da vida enquanto tal, pois eles se referem somente à forma, produto posterior da representação. Vejamos a seguinte passagem das notas, que me parece bastante elucidativa quanto a isso: “Não é 'uma vida' que deve ser produzida, e para isso é preciso procurar por formas, mas sim: 'sob tal forma, uma 'vida' deve aparecer (erscheinen)" (NF/FP 62[52], KGW I/4.574). O que esse trecho nos sugere? Segundo o entendo, ele sugere que nossos modelos de compreensão do organismo não explicam a produção da vida, mas a produção de uma forma na qual a vida aparecerá enquanto fenômeno (erscheinen). Aqui, a vida é posta como pressuposto, e o modelo explicativo escolhido só buscará dar conta da forma na qual a vida aparece: "Aquilo, portanto, que é causa enquanto representação do efeito, é apenas a forma da vida. A vida mesma não pode ser pensada como fim, pois ela está pressuposta na atividade conforme a fins" (NF/FP 62[46], KGW I/4.570). ${ }^{9}$ Essas reflexões dão testemunho da admissão por parte de Nietzsche de um tipo de vitalismo, na medida em que a vida é tida como pressuposto da pergunta pelo surgimento do organismo, que converte-se numa pergunta pelo surgimento da forma na qual a vida aparece. Esta última, por sua vez,

9 Cf. ainda NF/FP 62[29], KGW I/4.561: “chamamos conforme a fins apenas aquilo que é capaz de vida. O segredo é somente 'a vida'. Será que ela também é apenas uma ideia condicionada na organização?” A pergunta colocada por Nietzsche aponta para o que parece ser sua posição própria: a vida não pode ser uma ideia condicionada por nossa organização, pois nossa organização mesma depende da vida. A vida é aquilo em nós de que dependem todas as atividades orgânicas e intelectuais possíveis. Reduzir a vida a uma ideia condicionada pela organização é inverter a relação condicional: é a organização que depende da vida, não o contrário. 
Natureza, vida e finalismo nas notas sobre a teleologia e sobre a origem da linguagem de Nietzsche (1868-69)

é considerada irredutível à explicação mecânica, que buscará dar conta do surgimento da forma.

Nesse contexto, a vida é pensada como presença constante em tudo o que existe, pois ela se refere justamente à dimensão da produtividade da natureza: toda e qualquer ontogênese pressupõe este princípio vital. Quando Nietzsche diz que não é a vida que deve ser produzida, mas sim uma forma específica na qual esta vida aparecerá, ele substitui o que em Schopenhauer era a vontade una, que se exterioriza e se objetiva numa multiplicidade de fenômenos, por um princípio, ele mesmo múltiplo e em constante devir, que se manifesta em formas naturais determinadas, as quais, por sua vez, não são senão arranjos provisórios que abarcam em si mesmos uma parte daquela multiplicidade. Em última instância, porém, o devir incessante permanece inapreensível.

Precisamos das causas finais para explicar que algo vive? Não, somente para explicar como ele vive.

Precisamos das causas finais para explicar a vida de uma coisa?

Não, a "vida" é algo para nós inteiramente obscuro, sobre o qual não somos capazes de lançar nenhuma luz nem mesmo mediante causas finais.

$\mathrm{O}$ que tentamos tornar claro para nós são somente as formas da vida (NF/ FP 62[47], KGW I/4.571).

Mas o caráter obscuro da vida é incontornável. Como devemos entender então essa dimensão de uma produtividade incessante designada pelo termo "vida"? Por mais que demonstre sua adesão ao empedoclismo e ao darwinismo enquanto alternativas à teleologia antropomórfica (alternativas muito mais promissoras e epistemicamente mais bem fundamentadas), Nietzsche não abandonou a tentativa de determinar uma interioridade nos processos de individuação que ultrapassa o escopo do mero mecanismo. ${ }^{10}$ Essa

10 Nietzsche tende, nessas notas, a associar a explicação causal do modelo mecânico à tese de que os organismos surgem a partir de uma combinação de acasos favoráveis, sem a atuação de nenhuma força dotada de intencionalidade (causalismo e casualismo estão aqui essencialmente conectados). Tal tese é formulada com base na associação apresentada por

Cad. Nietzsche, Guarulhos/Porto Seguro, v.41, n.3, setembro-dezembro $2020 \mid 137$ 
tentativa, schopenhaueriana em sua essência mas anti-schopenhaueriana nos seus resultados, nem sempre é explícita. Num dos poucos momentos das notas em que ensaia uma qualificação dessa dimensão interior, Nietzsche diz que não podemos conceber a vida, isto é, a "existência sensível e florescente", a não ser a partir de uma analogia com o humano (NF/FP 62[54], KGW I/4.576). ${ }^{11}$ Evidentemente, não se trata mais de atribuir um tipo de racionalidade à natureza. A consistência e a legitimidade de uma tal visão dependerão agora do grau e do teor dessa analogia. Que tipo de características encontradas em nós devemos projetar na natureza para que possamos ensaiar uma compreensão de sua produtividade, e em que grau devemos pressupô-las em seus processos de produção? A

Lange entre Darwin e Empédocles (Lange, 1866, pp. 401s.; cf. sobre isso Mattioli, 2018a, p. 108). Aproveito esta ocasião para tecer algumas breves considerações a partir do artigo de Daniel Temp (2019), publicado recentemente sobre este tema. Diferentemente do que afirma Temp (2019, pp. 208ss.), penso que o quadro geral do argumento indicado acima nos permite supor que a noção de "acaso" aparece em oposição não só à noção de "racionalidade", mas a qualquer forma de "intencionalidade" (como a intencionalidade não-racional pressuposta, de forma opaca, na teleologia schopenhaueriana, por exemplo). Se é verdade que Lange ainda mantém o termo Zweckmäßigkeit, por outro lado é também verdade que ele retira-lhe toda conotação teleológica em sentido próprio (cf. Lange, 1866, pp. 404s.). A noção de "teleologia" ou "conformidade a fins" que nos resta neste contexto se reduz à ideia de uma regularidade $\mathrm{e}$ de uma ordenação natural subsumível aos conceitos do modelo estritamente mecanicista (cf. sobre isso: Michelini, 2007, pp. 233ss.). Assim, ela passa a significar não mais "conformidade a fins" em sentido próprio, mas pura e simplesmente "conformidade a leis" (no caso, às leis mecânicas do movimento da matéria).

11 Esta me parece ser a primeira ocorrência explícita, na obra de Nietzsche, do argumento analógico de inspiração schopenhaueriana, que será retomado especialmente nos póstumos da década de 80, com a fórmula "o corpo como fio condutor", e que responde, como argumenta Lopes (2014, p. 101), a um "crescente interesse de Nietzsche, na virada da primeira para a segunda metade dos anos 1880, na reabilitação da atividade especulativa." Nesse sentido, acredito que a noção de Lebenskraft, que aparece nessas notas de juventude como operador conceitual que delimita o domínio fonte do argumento analógico, pode ser vista como uma prefiguração da noção de vontade de poder, mediante a qual o Nietzsche maduro desenvolverá sua argumentação em torno da relação entre corpo e mundo. Infelizmente, este não é o lugar para uma discussão mais detida acerca da relação entre essas notas de juventude, com seu conceito de força vital, por um lado, e as reflexões tardias sobre a vontade de poder, por outro. Espero poder desenvolver melhor essa discussão em outra ocasião. A aproximação entre a força vital dessas notas e a vontade de poder das notas de maturidade é sugerida também por Crawford (1988, pp. 125ss.), apesar de a autora não fazer menção à ocorrência do argumento analógico nos apontamentos de juventude, nem discuti-lo diretamente tal como ele aparece na obra madura. 
Natureza, vida e finalismo nas notas sobre a teleologia e sobre a origem da linguagem de Nietzsche (1868-69)

primeira dica presente nessa nota é que devemos entender a vida como algo em constante crescimento e cujos processos são marcados por um tipo de sensibilidade. ${ }^{12}$ Pouco antes dessa anotação encontramos a mesma qualificação: “A 'vida' entra em cena com a sensação" (NF/FP 62[52], KGW I/4.575). A sequência dessa nota é ambígua, na medida em que parece recair num antropomorfismo mais grosseiro: "Viver' é existir conscientemente, isto é, de modo semelhante ao humano" (NF/FP 62[52], KGW I/4.575). Logo em seguida, porém, é colocada a questão: "Na ausência de uma consciência de si?" (NF/FP 62[52], KGW I/4.576). O que temos aqui parece ser uma tentativa de definir a sensação como um tipo de consciência fenomenal elementar. Ser capaz de sensação equivaleria, nesse caso, a ser capaz de algum nível de consciência fenomenal, tanto mais opaca quanto menos complexa e articulada for o tipo de sensação que temos em mente. O segundo trecho deixa claro, por sua vez, que ele exclui a autoconsciência desta associação (que é o tipo de consciência que normalmente associamos à articulação conceitual). Nesse sentido, tudo que vive tem alguma forma de sensação e, assim, alguma forma de consciência. Trata-se obviamente de uma noção deflacionada de consciência.

Devido ao tipo de texto com o qual estamos nos confrontando, não é de espantar que nos deparemos com sentenças aparentemente paradoxais e com apontamentos que parecem destoar do suposto sentido mais geral das notas. De todo modo, seguindo o princípio de caridade interpretativa, o que podemos extrair das dicas que nos são dadas por Nietzsche nessas passagens é que, na medida em que considerarmos a vida somente enquanto se manifesta exteriormente nos organismos que percebemos como objetos, nosso foco recai sobre sua forma. Esse modo de consideração pode nos conduzir, por um lado, à ideia de uma conformidade a fins de tipo kantiano ou, por outro, à tese epistemicamente menos onerosa do

12 A caracterização da vida nesses termos (sensibilidade e crescimento) parece retomar alguns aspectos da definição da Lebenskraft, tal como vimos na nota 9 acima.

Cad. Nietzsche, Guarulhos/Porto Seguro, v.41, n.3, setembro-dezembro $2020 \mid 139$ 
mecanicismo, restituída de seu poder explicativo pelo advento do darwinismo. Porém, se considerarmos a vida na medida em que se manifesta em nós mesmos, teremos uma compreensão a partir de dentro. Trata-se de uma abordagem fenomenológica: na medida em que estamos vivos, temos uma compreensão íntima da condição de vivente a partir da perspectiva de primeira pessoa (Hill, 2003, p. 93). Se formos então capazes de nos valer com parcimônia e de um modo um tanto quanto minimalista dessa compreensão fenomenológica, concluiremos que a vida não exige o grau ou o tipo de consciência que encontramos em nós; tampouco racionalidade, uma vez que esta se encontra indissociavelmente ligada à ideia de consciência tal como a encontramos em nós. Mas a vida exige algo como sensação, o que torna possível um "trabalho inconsciente" das partes do organismo em conjunto (NF/FP 62[54], KGW I/4.576). Esse trabalho conjunto, por sua vez, depende de um tipo de percepção mútua e se encontra orientado por um fim. O fim é a vida mesma - não em geral ou a vida enquanto tal, mas a vida do e no organismo, isto é, a vida nessa forma específica. ${ }^{13}$ Nesse sentido, podemos dizer que esse trabalho inconsciente das partes depende de um tipo de intencionalidade que difere fundamentalmente da intencionalidade que atribuímos às nossas ações racionais conscientemente elaboradas. Se esta tese estiver correta, devemos concluir que a noção nietzscheana de vida está associada a um tipo de vitalismo que é receptivo a certos princípios teleológicos minimais (associados à ideia de uma conformidade a fins interna), mas que não dependem de uma tese antropomorficamente inflacionada. A expressão conceitual dessa posição estaria manifesta na ocorrência do termo Lebenskraft como um dos tópicos a serem desenvolvidos como capítulos do seu trabalho de doutoramento.

No que se segue, analisarei em que medida a crítica de Nietzsche à oposição kantiana entre mecanismo e teleologia pode for-

13 Lembremos aqui da tese de Virchow, citada por Lange, segundo a qual o indivíduo orgânico deve ser concebido como "uma comunidade unitária, na qual todas as partes trabalham em conjunto para um fim semelhante" (Lange, 1866, p. 407). 
Natureza, vida e finalismo nas notas sobre a teleologia e sobre a origem da linguagem de Nietzsche (1868-69)

necer mais subsídios para nossa tese de que o compromisso de Nietzsche com uma explicação puramente mecanicista dos fenômenos naturais não deve ser sobrestimado.

\section{A supressão dos limites entre mecanismo e teleologia}

Dissemos anteriormente que a tese nietzschiana segundo a qual nosso conceito de unidade é relativo - de onde se conclui que toda unidade, seja ela orgânica ou inorgânica, envolve uma multiplicidade - está associada à tentativa de suprimir os limites entre mecanismo e teleologia. Isso pode ser explicado da seguinte forma. A indeterminação do nosso conceito de indivíduo; a dependência desse conceito em relação à noção de forma; a conclusão de que nosso conceito de conformidade a fins se refere justamente à forma; e a constatação de que esta última, além de pertencer ao modo como nos representamos o mundo, é uma característica que pode ser encontrada também em fenômenos inorgânicos, como os cristais; tudo isso conduz Nietzsche ao seguinte argumento: se somos obrigados a reconhecer um tipo de princípio teleológico nos organismos, devemos reconhecê-lo também em certos domínios do mundo inorgânico: "De fato, somos obrigados a perguntar por causas finais também no caso do cristal que se desenvolve" (NF/FP 62[47], KGW I/4.571). O fenômeno da cristalização é um exemplo emblemático de que o critério formal que supostamente tornaria necessário o apelo a princípios teleológicos se aplica igualmente a conjuntos de fenômenos que ultrapassam a esfera do orgânico. "A dedução de que os organismos são os únicos fins da natureza não logrou êxito" (NF/FP 62[43], KGW I/4.566).

$\mathrm{O}$ cerne do argumento em questão consiste em mostrar que não estamos autorizados a lançar mão de dois modelos teóricos distintos para explicar os fenômenos orgânicos e inorgânicos, argumento que já estava presente no movimento de relativização do conceito 
de unidade: "devemos conceder que, na natureza orgânica, no comportamento dos organismos uns com relação aos outros, não existe nenhum outro princípio além daquele existente na natureza inorgânica" (NF/FP 62[45], KGW I/4.568). Nesse sentido, o dualismo entre mecanismo e teleologia deve ser suprimido. A essa supressão corresponde, em última instância, a supressão da distinção entre juízo determinante e juízo reflexivo no vocabulário kantiano.

Apesar de, em certos momentos das notas, Nietzsche parecer concordar com a distinção proposta por Kant, ${ }^{14}$ a progressão das notas não deixa dúvidas quanto ao fato de que a posição final de Nietzsche corresponde a uma recusa da tese de que estejamos, em alguma medida, constrangidos a lançar mão de modelos explicativos distintos ao abordar os fenômenos orgânicos e os inorgânicos: "Causas finais, assim como o mecanismo, são formas humanas de percepção. Apenas o matemático é conhecido de modo puro. A lei (na natureza inorgânica) é, enquanto lei, algo análogo às causas finais." (NF/FP 62[39], KGW I/4.64). O resultado dessa operação (de supressão dos limites entre orgânico e inorgânico, entre mecanismo e teleologia) é dúbio: por um lado, se não precisamos de um princípio teleológico para explicar a causalidade presente no mundo inorgânico, tampouco precisamos de um tal princípio para compreender os fenômenos orgânicos. Essa alternativa corresponde à alternativa encontrada pelo materialismo, ao qual muitas vezes Nietzsche parece se filiar. Por outro lado, porém, podemos pensar da seguinte forma: se precisamos de um princípio teleológico para compreender os fenômenos orgânicos, necessitaremos também de algum tipo de princípio teleológico para explicar e conceder unidade à regularidade dos fenômenos inorgânicos. Ao contrário do que seria de esperar, dado o tom geral das notas, em alguns momentos Nietzsche parece estar mais inclinado a essa segunda alternativa. Como afirma Lopes, Nietzsche "sugere uma redução das causas mecânicas a causas finais e do uso constitutivo ao uso reflexivo

14 Cf. por exemplo NF/FP 62[24], KGW I/4.558 e 62[27], KGW I/4.559. 
Natureza, vida e finalismo nas notas sobre a teleologia e sobre a origem da linguagem de Nietzsche (1868-69)

da faculdade de julgar" (Lopes, 2008, p. 151). A redução do caráter constitutivo dos juízos determinantes a um caráter meramente regulativo tornaria despovoada a classe de juízos explicativos e, segundo Lopes, indicaria o primeiro passo de Nietzsche rumo a um ficcionalismo generalizado. ${ }^{15} \mathrm{Em}$ uma passagem crucial, Nietzsche cita Kant e conclui, em contraposição a este, que todos os juízos que denominamos determinantes não passam de juízos reflexivos:

"Só podemos compreender plenamente aquilo que nós mesmos podemos construir e trazer à existência segundo conceitos."

15 Na esteira da interpretação de Lopes, Ricardo Dalla Vecchia (2014, p. 115) procura mostrar que esse movimento argumentativo do jovem Nietzsche configura o que poderíamos chamar de "protótipo do perspectivismo", uma vez que ele implica na tese de que todos os juízos supostamente explicativos corresponderiam tão somente a hipóteses regulativas de caráter ficcional. A noção de conformidade a fins seria igualmente fruto de uma atividade de interpretação e ficcionalização que, por sua vez, seria "expressão de um poder inconsciente, que cria e se serve do conhecimento para as funções vitais como fortalecimento, crescimento, preservação." (Dalla Vecchia, 2014, p. 116) Ao que tudo indica, a recondução proposta por Dalla Vecchia da atividade de interpretação a um "princípio vital", nesse contexto, corresponde a uma tentativa de ver aqui uma antecipação da relação essencial, estabelecida por Nietzsche em sua obra de maturidade, entre perspectivismo e vontade de poder. Segundo essa concepção, é a própria atividade das vontades de poder que deve ser vista como "interpretante", ou seja, as vontades de poder são elas mesmas processos de interpretação. Essa é a tese central do perspectivismo maduro de Nietzsche, que atribui aos componentes volitivos de sua ontologia especulativa qualidades de agentes cognitivos, daquilo que podemos chamar, para usar um termo de Dennett (1996, 34ss.), de "sistemas intencionais". A nosso ver, há aqui uma noção deflacionada de conformidade a fins, na medida em que todo querer é sempre um querer-algo, ou seja, possui uma estrutura minimamente teleológica, pois está direcionado a um "fim" (cf. Stack, 1983, p. 246s.; Richardson, 1996, p. 21). Das qualidades cognitivas e intencionais atribuídas a estes componentes volitivos Nietzsche extrai sua capacidade para o estabelecimento de acordos políticos (cf. sobre isso: Lopes, 2017), com base nos quais a relação agonística entre tais "agentes" é organizada de modo a tornar possível a manutenção de um sistema relativamente harmônico. Se assumirmos a tese de que o jovem Nietzsche, nas notas sobre a teleologia, vê no próprio conceito de conformidade a fins e na atividade interpretativa de forma geral a expressão de um poder inconsciente criador que se serve do conhecimento com vistas a uma intensificação das funções vitais (tese que é defendida também por Cavalcanti, 2005, p. 76), estaremos realocando a noção de conformidade a fins novamente no registro daquilo que antecede a própria conceitualização. Esse passo especulativo, que me parece estar de fato presente (mesmo que implicitamente) nas reflexões de Nietzsche, é o que o aproxima da Naturphilosophie de Schelling e Goethe, por um lado, e, por outro, do movimento de reabilitação da teleologia nas ciências da vida da época, a partir da constatação da insustentabilidade da distinção kantiana entre regulativo e constitutivo (cf. sobre isso: Zammito, 1998; Larson, 1979). Discuto esse último ponto no cap. III, seção 5.3, da minha tese de doutorado (Mattioli, 2016).

Cad. Nietzsche, Guarulhos/Porto Seguro, v.41, n.3, setembro-dezembro $2020 \mid 143$ 
Deste modo, apenas o matemático pode ser plenamente compreendido (ou seja, compreensão formal). Estamos de resto face ao desconhecido. Para administrá-lo, o homem inventa conceitos, que apenas unificam uma somatória de propriedades que se manifestam, mas não tocam a coisa.

A eles pertencem força, matéria, indivíduo, lei, organismo, átomo, causa final. Eles não são juízos constitutivos, mas tão somente juízos reflexivos. (NF/ FP 62[40], KGW I/4.565. Trad. Lopes, 2008, p. 152)

A ideia de que os conceitos científicos têm um caráter regulativo e, portanto, correspondem a ficções que nos auxiliam na assimilação da realidade, já havia sido proposta por Lange em sua crítica à interpretação dogmática da ciência (cf. Lopes, 2008, pp. 152s.). Essa parece ser uma das inspirações de Nietzsche. Por outro lado, é de Schopenhauer que parece provir a inspiração para a contestação da oposição kantiana entre orgânico e inorgânico, no tocante aos limites da explicação mecanicista. É de inspiração schopenhaueriana também o exemplo dos cristais, mencionado acima, e a ideia de que somente o matemático nos é conhecido de modo pleno e puro. Numa importante passagem ao final de sua Crítica da filosofia kantiana, publicada como apêndice ao primeiro tomo do Mundo, Schopenhauer reconhece uma lacuna na teoria kantiana da teleologia, que diz respeito ao fato de Kant ter circunscrito a impossibilidade de uma explicação mecânica apenas aos fenômenos orgânicos, ao passo que ele próprio buscará expandir à totalidade da natureza esta irredutibilidade ao mecanismo (Schopenhauer, 2005, pp. 661s.).

Já no livro II do primeiro tomo do Mundo, Schopenhauer insistia no caráter de imperscrutabilidade de toda força atuante na natureza, não apenas daquelas responsáveis pela formação de indivíduos orgânicos: "a força em virtude da qual a pedra cai na terra, ou um corpo repele outro, não é menos estranha e misteriosa em sua essência íntima do que aquela que produz os movimentos e o crescimento de um animal." (Schopenhauer 2005, p. 154) Em Parerga e paralipomena, ele desenvolve essas reflexões a par- 
Natureza, vida e finalismo nas notas sobre a teleologia e sobre a origem da linguagem de Nietzsche (1868-69)

tir de uma discussão acerca da oposição entre matéria e espírito. Ali, ele critica a crença na transparência da matéria, comum entre os materialistas dogmáticos, e sua convicção de que os fenômenos (sobretudo os inorgânicos) nos seriam acessíveis em sua essência mediante os conceitos científicos mecanicistas, e insiste na tese de que “toda força da natureza é algo imperscrutável." (P II, pp. 112s.)

Encontramos essa última afirmação refletida na seguinte passagem das notas de Nietzsche sobre a teleologia: "Toda causa eficiente repousa sobre algo inescrutável" (NF/FP 62[30], KGW I/4.561) Trata-se aqui da afirmação de uma interioridade dos fenômenos, afirmação com a qual já nos deparamos anteriormente. A tese segundo a qual essa interioridade não pode ser desvelada pela observação científica corresponde a um dos elementos nucleares da visão de mundo schopenhaueriana. $\mathrm{O}$ argumento de Schopenhauer que procura dissolver a dicotomia kantiana entre orgânico e inorgânico e esterilizar assim os conceitos científicos no tocante à explicação propriamente dita do mundo se constrói com base numa concepção metafísica, da qual deriva um tipo de vitalismo. ${ }^{16}$ Ao determinar positivamente o conteúdo da coisa em si, Schopenhauer estabelece ao mesmo tempo o único caminho capaz de nos levar a um conhecimento desta última - e esse caminho não é calcetado por conceitos científicos, que tocam somente no lado exterior do fenômeno. Antes, trata-se do conhecimento que o sujeito, enquanto indivíduo, tem de sua própria interioridade a partir da autoconsciência.

Em Lange, pelo contrário, os conceitos científicos gozam de um claro privilégio epistêmico frente aos conceitos metafísicos. A maior legitimidade epistêmica concedida por Lange aos conceitos científicos parece depender, além do princípio de economia, de um cálculo de probabilidade: ao servir de instrumento para a descrição mais exata possível do conjunto dos fenômenos e para a previsão de fenômenos futuros, é mais provável que eles correspondam efetivamente ao mundo objetivo. Em uma passagem do capítulo dedicado

16 Sobre isso, cf. Mattioli, 2018b.

Cad. Nietzsche, Guarulhos/Porto Seguro, v.41, n.3, setembro-dezembro $2020 \mid 145$ 
a questões antropológicas, ele diz que, mesmo frente aos pressupostos do idealismo, resta-nos ainda investigar a probabilidade de que o mundo dos fenômenos corresponda efetivamente ao mundo das coisas que os produzem, ao contrário do que diz Kant. Ou seja, talvez estejamos "autorizados a pensar que ao menos a matéria, com seu movimento, seja o fundamento objetivamente existente de todos outros fenômenos" (Lange, 1866, p. 497) Já no capítulo sobre o materialismo filosófico desde Kant ele havia afirmado que nada nos impede de supor que o terreno dos conhecimentos a priori se estenda para além dos limites das nossas representações, sugerindo que "a realidade transcendente do espaço e do tempo talvez possa, portanto, ser elevada a um alto grau de probabilidade" (Lange, 1866, p. 254)

Devido à sua concepção positiva da coisa em si, Schopenhauer é (talvez injustificadamente) mais radical do que Lange nesse aspecto em particular. Ao constatar uma lacuna na afirmação de Kant de que jamais seremos capazes de explicar os fenômenos orgânicos com base num modelo mecanicista, ele afirma que mesmo os fenômenos supostamente explicados por esse modelo permanecem, do ponto de vista do próprio mecanicismo, um enigma insondável. Frente àquela interioridade dos fenômenos naturais em geral, que Schopenhauer remeterá às forças primordiais e seus correspondentes metafísicos (as ideias platônicas), os conceitos da mecânica são absolutamente estéreis. Isso os coloca exatamente no mesmo registro dos juízos reflexivos kantianos. Esse fracasso explicativo é análogo ao fracasso ao qual estão fadadas nossas tentativas de explicar a unidade autorreguladora do organismo e o próprio pensamento mediante a aplicação dos modelos mecanicistas. Contra o pano de fundo desse voluntarismo (que, a meu ver, pode ser traduzido em termos vitalistas) os conceitos científicos possuem um valor cognitivo consideravelmente menor do que aquele do qual gozam no interior do falibilismo de Lange. 
Natureza, vida e finalismo nas notas sobre a teleologia e sobre a origem da linguagem de Nietzsche (1868-69)

Dentro desse contexto, Schopenhauer afirma que a finalidade da natureza orgânica tem o mesmo estatuto da legalidade da natureza inorgânica, uma vez que ambas são "introduzidas por nosso intelecto na natureza, e concernem tão somente ao fenômeno, não à coisa em si" (Schopenhauer, 2005, p. 223). Essa passagem é reproduzida por Nietzsche em suas notas: "a finalidade do orgânico, a legalidade do inorgânico são introduzidas por nosso entendimento na natureza" (NF/FP 62[7], KGW.551). Como está claro, ao contrário do que afirmam Emden (2014, p. 84) e Gentili (2010, p. 114), que remetem essa afirmação diretamente a Kant, o argumento apresentado aqui provém de Schopenhauer e, na medida em que pretende acompanhar o espírito geral da Crítica da razão pura, é, de fato, kantiano em sua motivação e em suas pretensões, mas é antikantiano nos seus resultados e, sobretudo, em seus pressupostos. Em primeiro lugar, ele aponta, como mencionado, para uma dissolução, ou ao menos uma relativização, da dicotomia entre princípios regulativos e constitutivos. A finalidade, que em Kant é o exemplo mais emblemático de princípio regulativo, parece ter, para Schopenhauer, o mesmo estatuto das proposições derivadas das formas puras do entendimento e da sensibilidade: tempo, espaço e causalidade. $\mathrm{O}$ que ele pretende, quando assume indiretamente o caráter regulativo do princípio de finalidade, é determinar sua origem e sua validade meramente subjetiva. Mas essa mesma origem e essa mesma validade são atribuídas por ele a toda a esfera do fenômeno.

Em Kant, o fenômeno em geral, isto é, tudo aquilo que apreendemos pela sensibilidade e experienciamos, via entendimento, como um mundo de coisas em relação umas com as outras - em suma, tudo aquilo que pode ser estudado pela física, com seu arcabouço conceitual (matéria, movimento, causalidade mecânica, etc.), estabelece o âmbito do uso constitutivo dos conceitos. A finalidade está, do ponto de vista das nossas possibilidades de compreensão, excluída desta dimensão, pois só a compreendemos com base num outro tipo de causalidade. Seu registro próprio é aquele 
dos organismos: é nele que reconhecemos a conformidade a fins natural através de sua unidade autorreguladora, em que as partes só são "possíveis por sua relação com o todo" e se ligam "à unidade de um todo em virtude de serem reciprocamente causas e efeitos umas das outras" (Kant, 2016, p. 269); e é justamente por isso que o organismo se apresenta como uma espécie de anomalia no fenômeno, irredutível a meros princípios mecânicos, e sobre cuja possibilidade e geração não podemos julgar a não ser que pensemos "em uma causa para elas que opera por intenções, portanto um ser que é produtivo segundo a analogia com a causalidade de um entendimento" (Kant, 2016, p. 293).

Disso resulta, segundo Kant, que jamais seremos capazes de conhecer suficientemente os seres organizados e sua possibilidade interna segundo meros conceitos mecânicos, razão pela qual é absurdo "esperar que possa surgir um Newton capaz de explicar a geração de um talo de grama que seja segundo leis naturais que nenhuma intenção tenha ordenado" (Kant, 2016, p. 296). Uma consequência importante dessa concepção é que a biologia jamais terá o mesmo estatuto científico que a física, isto é, jamais será efetivamente uma ciência, pois não pode abrir mão de juízos de finalidade. Schopenhauer, por sua vez, concorda com Kant que "é absurdo esperar por um Newton do ramo de relva", pois jamais poderemos reduzi-lo "a fenômenos de forças químicas e físicas" (Schopenhauer, 2005, p. 206). Mas ele se distancia de Kant em dois aspectos fundamentais. Em primeiro lugar, como indicado anteriormente, ele aponta uma lacuna no argumento kantiano, na medida em que "Kant nega essa possibilidade de explicação só no que tange à finalidade e à intencionalidade aparente dos corpos orgânicos" (Schopenhauer, 2005, p. 661), ao passo que ele pretende expandir essa irredutibilidade à natureza como um todo, de modo que nem mesmo "a solução de um sal na água, para não mencionar os fenômenos mais complicados da química", pode ser explicada "segundo as leis do mecanismo propriamente dito" (Schopenhauer, 
Natureza, vida e finalismo nas notas sobre a teleologia e sobre a origem da linguagem de Nietzsche (1868-69)

2005, p. 662). Com isso, a esfera dos juízos determinantes é esvaziada, e a distinção entre constitutivo e regulativo desaparece. Para ele, é como se, no âmbito do fenômeno, não houvesse princípios capazes de nos fornecer um conhecimento objetivo. Dado o caráter essencialmente subjetivo da representação, a única verdade propriamente "objetiva" (no sentido de uma realidade "extramental") à qual poderíamos chegar seria a realidade metafísica da vontade como essência do mundo. Frente a esta verdade, todos os juízos restantes, inclusive as proposições científicas, são deslocados para o âmbito de mero juízo regulativo, isto é, subjetivo.

Como nos indicam algumas passagens dos apontamentos discutidos aqui, essa dissolução schopenhaueriana da dicotomia entre organismo e mecanismo com base num tipo de vitalismo teve um efeito importante sobre a concepção desenvolvida pelo jovem Nietzsche. O que não quer dizer que ele esteja se comprometendo com a tese metafísica da vontade como essência do mundo. Os termos nos quais ele desenvolverá esse vitalismo são devedores da tese, inspirada diretamente em Lange e fundamentalmente anti-schopenhaueriana, segundo a qual o conceito de unidade não se aplica à dimensão pré-individual, de modo que aquilo que antecede à constituição pelo entendimento do mundo como representação deve ser pensado em termos de uma multiplicidade produtiva. Em consonância com isso, o conceito de vontade é substituído pela noção de vida. Por sua vez, ao sugerir uma redução da causalidade mecânica a causas finais, Nietzsche, na esteira de uma certa vertente do vitalismo e do que podemos chamar de visão orgânica do mundo, parece atribuir um tipo de teleologia aos processos de produção no interior daquela multiplicidade vital. ${ }^{17}$

17 Como observa Toscano (2001, p. 55), Nietzsche aponta para uma expansão do âmbito da conformidade a fins para muito além do orgânico, expandindo-o talvez indefinidamente. Nesse sentido, assim como nos apontamentos de Leipzig ele havia expandido infinitamente os limites da representação (cf. Mattioli, 2018a, p. 91), mas aparentemente entendendo a representação num sentido deflacionado e não intelectualista, ele pode estar aqui expandindo os limites da teleologia e da conformidade a fins, mas entendendo o tipo de intencionalidade pressuposto por estes conceitos também num sentido completamente deflacionado, não intelectualista e

Cad. Nietzsche, Guarulhos/Porto Seguro, v.41, n.3, setembro-dezembro $2020 \mid 149$ 


\section{Teleologia e conformidade a fins no texto Sobre a origem da linguagem}

Para concluir minha análise contextual, gostaria de abordar brevemente o texto Sobre a origem da linguagem, escrito um ano depois das notas sobre a teleologia, como introdução a um curso de gramática latina oferecido por Nietzsche em 1869-70, já como professor na universidade de Basel. Veremos que a atitude assumida por ele, então, frente à questão da teleologia é bem mais explícita e positiva. Provavelmente no intuito de despertar em seus alunos um interesse genuinamente filosófico pelo estudo das formas gramaticais da linguagem, Nietzsche busca fundamentar sua abordagem numa teoria que identificava nessas formas uma estrutura cognitiva originária cuja organicidade remonta aos fundamentos da própria natureza. A noção de instinto, extraída de Eduard von Hartmann e da qual o jovem professor lança mão para explicar a origem da linguagem, traz consigo a ideia de uma conformidade a fins que se estende desde as formas orgânicas e suas condições materiais até a estrutura da linguagem. É com vistas a essa conformidade a fins que Nietzsche estabelece repetidamente analogias entre a linguagem e o organismo. Em uma passagem crucial, ele nota: "este é o verdadeiro problema da filosofia, a infinita conformidade a fins dos organismos e a ausência de consciência em sua gênese." (NF/FP, KGW II/2.186)

O que Nietzsche designa aqui como o verdadeiro problema filosófico se refere à constatação da existência de um tipo de teleologia que dispensa a ideia de fim posto por uma consciência. Essa conformidade a fins inconsciente é, como argumentará o filósofo,

minimalista em termos de antropomorfização. Trata-se de um movimento que não é sem precedentes, uma vez que Nietzsche já havia encontrado as primeiras indicações de uma concepção dessa natureza em Schopenhauer, mesmo que de modo bastante paradoxal. Ademais, ele provavelmente se confrontou com esse tipo de pensamento em suas possíveis leituras de autores que defendiam uma visão orgânica do mundo ou se valiam da noção de Lebenskraft em suas reflexões sobre as ciências da vida (como Herder, Goethe, Schelling, entre outros que são mencionados em seus apontamentos). 
Natureza, vida e finalismo nas notas sobre a teleologia e sobre a origem da linguagem de Nietzsche (1868-69)

o que caracteriza o instinto, do qual emana a linguagem. Por sua vez, é somente a partir desta última que se torna possível qualquer articulação do pensamento consciente. $\mathrm{O}$ argumento de Nietzsche que conduz da identificação do verdadeiro problema filosófico à existência de uma conformidade a fins inconsciente parte de uma tentativa de determinar o tipo de abordagem mais adequada ao problema das origens da linguagem. A pergunta que serve como fio condutor para as análises do jovem filólogo é, portanto: como e de onde surge a linguagem? Sua resposta é, a princípio, negativa, na medida em que nos diz como ela não pôde ter surgido: "a linguagem não é obra consciente de indivíduos, nem de uma maioria" (NF/FP, KGW II/2.185) Ela seria algo demasiadamente complicado para o trabalho individual e demasiadamente unitária para o trabalho consciente e refletido de um grupo massivo de indivíduos. O caráter orgânico do qual dá testemunho a complexidade de suas formas estruturais (para Nietzsche, a linguagem é um todo orgânico - "ein ganzer Organismus") só nos deixa uma opção: entendê-la como produto do instinto e de sua conformidade a fins. Após rejeitar uma série de hipóteses de diferentes pensadores acerca da origem da linguagem, Nietzsche afirma que o verdadeiro conhecimento de tal origem só nos é possível depois de Kant, o qual, "em sua Crítica da faculdade do juízo, ao mesmo tempo reconheceu a teleologia na natureza como algo efetivamente existente e, por outro lado, salientou a maravilhosa antinomia segundo a qual há algo conforme a fins sem uma consciência. Esta é a essência do instinto" (NF/FP, KGW II/2.188). ${ }^{18}$

18 Ao sugerir que, com o conceito kantiano de teleologia, um conhecimento correto sobre as origens da linguagem nos seria agora possível, Nietzsche comete um deslize de interpretação no que diz respeito à posição kantiana. Ele afirma, com efeito, que Kant "reconheceu a teleologia na natureza como algo efetivamente existente" (NF/FP, KGW II/2.188), sublinhando em seguida a centralidade da ideia de uma conformidade a fins inconsciente. Ora, sabemos que Kant não entende a teleologia como "algo efetivamente existente" na natureza, mas sim como um princípio regulativo da faculdade do juízo. Ademais, o que dá suporte ao emprego da teleologia (mesmo que hipotético e heurístico) na reflexão acerca da natureza é, aos olhos de Kant, o recurso à ideia de uma consciência superior, de uma inteligência ordenadora atribuída a uma entidade divina. Portanto, os atributos "efetivamente existente" e "inconsciente" não seriam

Cad. Nietzsche, Guarulhos/Porto Seguro, v.41, n.3, setembro-dezembro $2020 \mid 151$ 
É interessante notar aqui que este é um dos primeiros usos filosoficamente relevantes do conceito de instinto na obra de Nietzsche. ${ }^{19}$ Na primeira parte deste estudo, ${ }^{20}$ tivemos ocasião de discutir uma importante passagem das notas sobre a teleologia, na qual ele se refere a um poder inconsciente criador de formas na natureza, cuja atividade deve ser vista como conforme a fins e cuja manifestação mais evidente seria o instinto dos animais. Esse exemplo é retirado de Schopenhauer, e o uso do termo "instinto" no texto Sobre a origem da linguagem guarda certamente uma continuidade fundamental com o sentido presente nas notas sobre a teleologia. Contudo, a fonte de Nietzsche agora não é mais Schopenhauer, e sim Eduard von Hartmann, como já foi apontado pelos intérpretes que reconheceram no texto em questão a influência direta e decisiva do autor da Filosofia do inconsciente (1869). ${ }^{21}$ A definição hartmanniana de instinto como uma atividade conforme a fins sem a consciência da finalidade, que pode ser encontrada no capítulo " $\mathrm{O}$ inconsciente no instinto" (cf. Hartmann 1869, 54), desempenha um papel fundamental em todas suas reflexões sobre a relação entre o inconsciente e suas manifestações, tanto no comportamento animal

inteiramente adequados para uma descrição da teleologia tal como entendida por Kant. Se nos deparamos aqui realmente com um deslize de interpretação ou com uma apropriação intencionalmente unilateral por parte de Nietzsche, ao modo das interpretações de Schelling ou de Goethe, por exemplo, não é tão importante para o escopo de nossa investigação. O mais interessante é notar como esse deslize ou reapropriação lança uma luz sobre a posição assumida pelo próprio Nietzsche a partir de sua leitura de Hartmann. Se nas notas discutidas anteriormente sua posição acerca da teleologia era permeada de ambiguidades e parecia tender em grande parte do tempo a uma crítica inspirada numa concepção mecanicista ou darwinista, agora Nietzsche não apenas assume claramente uma posição favorável à teleologia, como acredita que é somente com base numa tal posição que podemos compreender a origem da linguagem.

19 Sua definição do instinto, baseada na Filosofia do inconsciente de Hartmann, ressalta seu componente teleológico e sua irredutibilidade ao mecanismo: "O instinto, porém, não é resultado da reflexão consciente, não é mero efeito da organização corporal, não é o resultado de um mecanismo disposto no cérebro, não é efeito de um mecanismo que alcança o espírito vindo de fora, estranho à sua essência, mas sim o poder mais próprio do indivíduo ou de uma massa, que emana do caráter. $\mathrm{O}$ instinto é até mesmo idêntico à quintessência mais íntima de um ser." (Nachlass/FP, KGW II/2.186)

20 Cf. Mattioli, 2018a, pp. 100ss.

21 Cf. Crawford, 1988; Thüring, 1994. 
Natureza, vida e finalismo nas notas sobre a teleologia e sobre a origem da linguagem de Nietzsche (1868-69)

em geral quanto no pensamento humano em particular. Esta noção, que implica uma concepção teleológica da natureza em harmonia com os resultados das ciências empíricas, ocupará o lugar central das reflexões de Nietzsche sobre a linguagem neste momento.

Entre os anos de 1868 e 1869, diversos apontamentos sugerem um crescente interesse de Nietzsche pela incorporação da filologia às ciências naturais. ${ }^{22}$ Sob o título "Naturwissenschaftliche Elemente" (elementos científico-naturalistas), encontramos os seguintes tópicos: "Exposição da vida pulsional (Triebleben), das leis, etc. [...] Origens da linguagem, darwinismo" (NF/FP, KGW I/5.379). Em um outro conjunto de notas, que antecedem os fragmentos preparatórios para seu texto sobre Homero e a filologia clássica (que servirá de base para sua aula inaugural na Universidade da Basiléia), nos deparamos com as seguintes anotações: "1) conhecimento científico-natural da essência da linguagem / 2) consideração científico-naturalista da antiguidade" (NF/FP, BAW 5.268). Nos fragmentos preparatórios para a já mencionada aula inaugural, Nietzsche escreve que a filologia é "tanto história, quanto ciência natural, quanto estética", complementando que ela seria ciência natural "na medida em que busca perscrutar o instinto mais profundo do ser humano, o instinto linguístico" (NF/FP, BAW 5.272) Essa última passagem é reproduzida literalmente no texto da aula inaugural de 1869. ${ }^{23}$ Por fim, logo acima dos tópicos reunidos sob o título "Naturwissenschaftliche Elemente", lemos o seguinte:

É corrente a concepção segundo a qual a filologia lidaria somente com o pensamento estabelecido pela escrita, isto é, com homens do passado e sua compreensão do mundo, nunca diretamente com a natureza. [...] Contudo, quando buscamos entender estes homens excepcionais e seus pensamentos apenas como sintomas de correntes intelectuais, de instintos continuamente vivos, tocamos diretamente a natureza. Assim como quando avançamos até a origem da linguagem (NF/FP, KGW I/5.378).

22 Cf. sobre isso Gerratana, 1994, pp. 341ss.

23 Cf. Nachlass/FP, KGW II/1.249.

Cad. Nietzsche, Guarulhos/Porto Seguro, v.41, n.3, setembro-dezembro $2020 \mid 153$ 
Dois são os elementos mais importantes que se fazem presentes nessas diversas passagens: as noções de instinto (Instinkt) e de impulso ou pulsão (Trieb), e o problema da origem da linguagem como um problema propriamente científico, a ser investigado a partir de uma abordagem naturalista. No que diz respeito à relevância do problema das origens da linguagem e ao movimento de recondução da linguagem ao registro pulsional ou instintivo, a influência da leitura de Hartmann nesse período parece ser decisiva. Gerratana (1994, pp. 343s.) considera que a influência de Hartmann foi responsável pelo que ele chama de "virada especulativa" do jovem Nietzsche nesse momento, e que está essencialmente associada à sua incorporação das noções de instinto e de inconsciente. Ao que tudo indica, a centralidade conferida pelo jovem filólogo ao componente científico-naturalista da filologia se deve ao reconhecimento de que somente uma investigação dessa natureza seria capaz de nos esclarecer acerca das origens da linguagem, uma vez que estas remontam ao instinto. Em Sobre a origem da linguagem, ele afirma que os constrangimentos e as dificuldades com as quais a pesquisa sobre as origens da linguagem se deparou no passado se justificavam pela falta de um conhecimento histórico e fisiológico adequado (NF/FP, KGW II/2.187), disponível agora graças ao avanço das ciências. Ou seja, um dos fatores principais que permitiram que um conhecimento justo acerca das origens da linguagem seja agora adquirido foi o desenvolvimento da fisiologia enquanto ciência, cuja contribuição para o estudo da linguagem seria devida justamente à sua capacidade de nos esclarecer acerca do âmbito instintivo ou pulsional.

Notemos, porém, que o modo como Nietzsche pensa o instinto nesse contexto corresponde a um modelo naturalista não reducionista. ${ }^{24}$ Há um componente teleológico fundamental que é constitutivo do instinto e irredutível ao mecanismo. Se isso é verdade, então Nietzsche está propondo que, caso se queira levar a sério a

24 Cf. nota 20 acima.

154| Cad. Nietzsche, Guarulhos/Porto Seguro, v.41, n.3, setembro-dezembro 2020 
Natureza, vida e finalismo nas notas sobre a teleologia e sobre a origem da linguagem de Nietzsche (1868-69)

possibilidade de integrar a filologia ao âmbito da ciência natural, os limites desta última devem ser expandidos para além dos limites da mera causalidade mecânica, sem que com isso seu status científico seja ameaçado. Com efeito, o reconhecimento da inevitabilidade do emprego de ficções conceituais nas explicações científicas, tal como expresso por Nietzsche nas notas sobre a teleologia, é inteiramente compatível com uma posição mais moderada ou liberal no que diz respeito à aceitabilidade de certos princípios teleológicos na ciência. Nesse contexto, o conceito de causa final, uma vez destituído de seu teor teológico, é colocado lado a lado com os conceitos de átomo, matéria e lei causal (NF/FP, 62[40], KGW I/4.565), como um dentre os muitos conceitos regulativos dos quais lançamos mão para compreender os fenômenos. Se essa leitura estiver correta, poderemos dizer, sem incorrer em nenhum absurdo interpretativo, que Nietzsche estaria então refletindo sobre a possibilidade de tornar a ciência permeável ao emprego parcimonioso de juízos de finalidade, certamente não como uma forma de reabilitar concepções de cunho teológico, mas por um interesse legitimamente cognitivo, com vistas a uma expansão da esfera do cientificamente explicável (se estivermos ainda dispostos a manter o conceito de "explicação"). Essa concessão modesta à especulação no âmbito da ciência, porém, o afasta do materialismo metódico de Lange e o aproxima de uma visão da ciência mais próxima daquela que permeava certas tendências românticas da época. Por sua vez, esse afastamento com relação ao programa de Lange implica igualmente um afastamento do darwinismo tal como apresentado por este último e discutido por Nietzsche em suas notas sobre a teleologia.

A título de conclusão, gostaria somente de ressaltar a importância de duas passagens que se encontram ao final de Sobre a origem da linguagem, extraídas de Herder e Schelling respectivamente: "A gênese da linguagem é um tal impulso interno (inneres Drängnis), como o impulso (Drang) do embrião ao nascimento no momento de sua maturidade." (NF/FP, KGW II/2.187) “Ocorre 
com a linguagem o mesmo que com o seres orgânicos; acreditamos vê-los se originarem de modo cego, e não podemos negar a imperscrutável intencionalidade de sua formação, até no menor detalhe." (NF/FP, KGW II/2.188) ${ }^{25}$ Essas duas passagens, entre as quais se encontra a menção à teleologia kantiana que citamos mais acima, estabelecem uma robusta analogia entre a linguagem e o organismo, concedendo especial atenção à conformidade a fins presente nesses dois registros. Assim, elas deixam transparecer de modo mais explícito a posição favorável de Nietzsche com relação à teleologia, que, neste momento, é certamente devedora de sua leitura da Filosofia do inconsciente de Hartmann. ${ }^{26}$

Se Nietzsche, em 1868, tivesse de fato abraçado sem ressalvas o darwinismo e o materialismo crítico contra qualquer concepção teleológica, me parece muito difícil explicar o que o teria levado, um ano depois, a incorporar com tamanha disposição intelectual as teses de Hartmann, Herder e Schelling acerca da conformidade a fins e da intencionalidade na natureza, assumindo ainda uma leitura enviesada da terceira Crítica de Kant, nos moldes daquela que serviu de ponto de partida para parte importante do romantismo.

\section{Breve excurso histórico sobre a noção de Lebenskraft}

A ocorrência da noção de Lebenskraft nas notas de Nietzsche sobre a teleologia pode ser vista, em conjunto com outras evidências, como mais um indicativo de que ele não está assumindo ali uma posição estritamente mecanicista. Dada a importância que a ideia de força vital adquire na leitura que proponho desses aponta-

25 Ao que tudo indica, a referência a Herder é retirada do livro de Theodor Benfey: Geschichte der Sprachwissenschaft, 1869 (cf. Cavalcanti ,2005, pp. 62-70; Thüring, 1994), ao passo que a referência a Schelling é retirada do próprio Hartmann (1869, p. 227), de quem Nietzsche toma emprestado várias passagens de seu texto.

26 Para uma discussão mais detalhada dos pontos mencionados brevemente aqui, remeto o leitor à minha tese de doutorado: $O$ inconsciente no jovem Nietzsche. Da intencionalidade das formas naturais à vida da linguagem (2016), em especial ao capítulo III. 
Natureza, vida e finalismo nas notas sobre a teleologia e sobre a origem da linguagem de Nietzsche (1868-69)

mentos, incluo aqui este breve excurso histórico sobre o conceito.

O conceito de Lebenskraft, como argumenta Goldmann (2011), remonta à literatura médica e antropológica do final do século XVIII, na qual é possível identificar os traços daquilo que virá a se constituir alguns anos depois como o movimento romântico. Trata-se, contudo, de um conceito que escapa a uma tentativa de definição unívoca. Ele parece se referir, em princípio, à força responsável pelos movimentos involuntários do corpo, como o metabolismo, a digestão e os batimentos cardíacos, para os quais uma explicação puramente mecânica não parecia satisfatória, mas que não poderiam ser remetidos de modo consequente à atividade da alma, uma vez que ocorrem de forma inteiramente inconsciente. A Lebenskraft aparece assim como um terceiro princípio ou substância, ao lado da alma e do corpo material. Ela está associada ainda à sensibilidade e à irritabilidade, isto é, à capacidade de perceber estímulos e de reagir a eles, assim como aos processos de constituição orgânica (força vital plástica).

Um dos autores que atribuíram um papel central a esse conceito na formulação de suas teorias, entre 1785 e 1791, foi Johann Gottfried Herder. Para este último, a Lebenskraft seria responsável pela organização e pela harmonização das partes do organismo numa totalidade. Trata-se de uma força genética, inata, com função de assimilação, secreção, formação orgânica, e que, em última instância, constitui o fundamento de nossas forças naturais, o "gênio interior de nosso ser" (Goldmann 2011, 127). Esse conceito foi igualmente importante para a fisiologia de Johann Friedrich Blumenbach, autor que, juntamente com Kant, foi responsável pelo estabelecimento de um programa científico para a pesquisa biológica da época (cf. Lenoir, 1981). Blumenbach, que foi talvez o maior representante, no período, da teoria epigenética acerca do desenvolvimento dos organismos, afirma que uma energia vital, em última instância indefinível, manifesta-se de vários modos nos vários processos orgânicos. $\mathrm{O}$ termo força, aplicado aos efeitos observáveis dessa energia, tinha a função de unificar tais efeitos em torno de um princípio teleológi- 
co (Larson 1979, p. 235). Além do conceito de Kraft, Blumenbach mobilizou também o conceito de Trieb. Seria possível constatar, em todos os corpos organizados, um impulso formativo (Bildungstrieb), cujos efeitos não podem ser reduzidos às meras forças físicas e químicas. A Lebenskraft seria, assim, uma determinação universal de todos os organismos e, enquanto tal, constituiria a base da própria fisiologia (Larson, 1979, p. 236).

Essa noção foi recebida por pesquisadores que viriam a desempenhar um papel crucial no desenvolvimento ulterior do romantismo, como Goethe e Humboldt (Goldmann, 2011, p. 129). O jovem Goethe, como observam Gödde e Buchholz (2011, p. 25), se inspirou na visão de mundo de Herder, segundo a qual o homem deve ser pensado como um organismo atravessado pelas forças inconscientes da natureza. A "visão orgânica do mundo" comum a essas concepções vitalistas teve uma influência decisiva também para o desenvolvimento da filosofia da natureza de Schelling. Apesar de criticar o emprego do conceito de Lebenskraft como uma capitulação da razão frente ao problema da perscrutabilidade e da inteligibilidade dos processos de produção da natureza (cf. Goldmann, 2011, p. 133; Richards, 2002, p. 293s.), Schelling compartilha de teses centrais que, sobretudo na concepção de Herder, fundamentavam o quadro teórico vitalista no qual o conceito de força vital tinha suas raízes (cf. Beiser, 2013, pp. 36s.; Gödde, 2009, pp. 37ss.). Algumas dessas teses correspondem à concepção dinâmica e à visão teleológica da natureza, ambas constitutivas da visão orgânica de mundo. Schelling se vale do conceito de Bildungstrieb de Blumenbach para caracterizar a dinâmica dos processos orgânicos e, indo além, eleva este conceito a um princípio especulativo que designa uma tendência universal da natureza, entendida como totalidade orgânica (cf. Reill, 2005, pp. 214s.). É em seu Sistema do idealismo transcendental (1800) que o termo "inconsciente" aparece pela primeira vez na forma substantivada, referindo-se à espontaneidade absoluta que está na base de todas as atividades da 
Natureza, vida e finalismo nas notas sobre a teleologia e sobre a origem da linguagem de Nietzsche (1868-69)

natureza e que configura a unidade incondicionada entre natureza e espírito (cf. Goldmann, 2011, p. 138; Völmicke, 2005, pp. 144194; Bowie, 2010, pp. 67s.).

Dentro desse contexto, é possível constatar um percurso que vai da noção de Lebenskraft à noção de inconsciente no interior da tradição romântica e vitalista (cf. Gödde 2009, pp. 42-54). 0 passo decisivo dessa transição foi dado pelo médico e filósofo Carl Gustav Carus, sob influência das filosofias da natureza de Goethe e Schelling. Carus, que diferentemente de Schelling mantém um uso positivo da noção de força vital, rejeita, seguindo aqui a tendência deste último, a separação entre força vital e alma, argumentando em favor de um psicovitalismo de cunho monista. Sua Psyche (conceito que dá título à sua obra principal publicada em 1846) constitui um princípio unitário de tudo que é vivo, no qual a separação entre corpo, força vital e alma é suprimida. A Lebenskraft é, assim, como que assimilada à unidade do psiquismo. Outro pressuposto básico de sua teoria é a desconstrução da identificação entre o psíquico (alma) e o consciente. A alma já se encontra em atividade muito antes do surgimento da consciência, como no estágio embrionário do desenvolvimento humano, por exemplo. O inconsciente seria não apenas o princípio originário num sentido genético, mas ainda o princípio fundamental da maior parte tanto da vida mental como da vida orgânica em geral (cf. Gödde, 2009, pp. 47s.; Goldmann, 2011, pp. 141s.). Apesar de ser Schelling o primeiro a empregar o termo inconsciente como substantivo, Carus foi o primeiro a fornecer uma conceitualização mais detalhada desse conceito.

Além destes dois últimos, Schopenhauer também ocupa um lugar importante no processo de transição da noção de Lebenskraft à noção de inconsciente. Em seu escrito Sobre a vontade na nature$z a$ (1836), ele critica os representantes do que ele chama de "materialismo grosseiro e estúpido" por negarem até mesmo a noção de "força vital", rebaixando a natureza a um jogo casual de forças físicas e químicas (Schopenhauer, 2013, p. 24. Na segunda edição 
da mesma obra, assim como no segundo volume de $O$ mundo como vontade e representação, ele acusa de plágio o médico dinamarquês J. D. Brandis, autor de Versuch über die Lebenskraft (1795), com vistas à sua identificação entre força vital e vontade. Schopenhauer argumenta que Brandis, em dois artigos publicados em 1833 e 1834, apropriou-se de sua concepção segundo a qual a fonte primordial de todas as funções vitais é uma vontade inconsciente, que deve ser reconhecida como o primum mobile da vida, apresentando então, sem qualquer referência ao autor, sua tese de que a Lebenskraft deve ser identificada àquela vontade inconsciente (Schopenhauer, 2015, pp. 314s.; 2013, pp. 53-60; cf. ainda Goldmann, 2011, p. 129; Mattioli, 2018b, pp. 216ss.). Essa tese é formulada por ele em Parerga e Paralipomena (P II, 175) nos seguintes termos: "A força vital é certamente idêntica à vontade; de modo que aquilo que se apresenta à autoconsciência como vontade, é, na vida orgânica inconsciente, aquele primum mobile da mesma, o qual foi muito adequadamente designado como força vital."

Por fim, um último nome deve ser destacado aqui, o de Adolph Trendelenburg. Apesar dos conceitos de força vital e de inconsciente não desempenharem um papel relevante na formulação de suas teorias, Trendelenburg foi um dos mais obstinados defensores da visão orgânica do mundo na primeira metade do século XIX. Sua filosofia, apresentada sobretudo nas Logische Untersuchungen (Investigações lógicas, publicadas pela primeira vez em 1840), tinha como meta a reabilitação da teleologia aristotélica no âmbito de uma reflexão especulativa, não nos moldes do idealismo hegeliano, criticado por ele, mas a partir das mais recentes pesquisas em embriologia e na fisiologia dos sentidos. Aqui, ele segue os passos de cientistas naturais tais como Johannes Müller, Virchow e von Baer (cf. Cruz, 2015). A fonte primária de sua visão de mundo parece ser, contudo, a filosofia da natureza de Schelling (cf. Beiser 2013, pp. 32-37). Beiser destaca os três aspectos centrais da visão de mundo de inspiração schellingeana defendida por Trendelenburg: o dinamismo, o monismo e o organicis- 
Natureza, vida e finalismo nas notas sobre a teleologia e sobre a origem da linguagem de Nietzsche (1868-69)

mo (teleologia). Trata-se aqui de uma clara reação à física cartesiana, de cunho estático, dualista e mecânico, e que teve uma influência decisiva no desenvolvimento do materialismo moderno.

Com exceção de Blumenbach, todos os nomes referidos aqui (Herder, Goethe, Schelling, Carus, Schopenhauer e Trendelenburg, além de J. Müller e Virchow) são mencionados por Nietzsche nas notas sobre a teleologia, seja no corpo de suas reflexões (Goethe e Schopenhauer), seja em suas listas de leitura. Não é possível afirmar com certeza quais dessas obras foram efetivamente lidas por ele nesse momento e qual o efeito que essas possíveis leituras tiveram sobre suas reflexões, mas essa lista de nomes pode ao menos lançar uma luz na nossa compreensão de qual era o contexto teórico a partir do qual o jovem filólogo e aspirante a filósofo estava pensando o problema da vida. Como vimos, alguns desses nomes, assim como algumas das teses apresentadas aqui, reaparecem no contexto das reflexões de Nietzsche sobre a relação entre linguagem e organismo e seu aspecto teleológico, entre 1869 e 1870.

Nature, Life and Purposiveness in Nietzsche's Notes on Teleology and On the Origins of Language (1868-69)

Abstract: This paper corresponds to the second of two parts that make up a study on the question of teleology in the notes of the young Nietzsche between 1867 and 1869. On the whole, the study intends to offer a reading of three sets of notes written by the philosopher in that period: Zu Schopenhauer, Zur Teleologie, and Vom Ur sprung der Sprache, with a clear focus on the notes on teleology of 1868. My aim is to show that, despite Nietzsche's various criticisms of teleology and his apparent adherence (via Lange) to Darwinism, his position is best understood as a kind of vitalism, which is receptive to the idea of an unconscious intentionality in nature, but explicitly rejects the anthropomorphically inflated conception of a divine designer. In this second part of the study, I close my analysis of the set of notes collected under the title Zur Teleologie and contextualize them in the horizon of the theses defended by Nietzsche in the text Vom Ursprung der Sprache, written a year later.

Keywords: Nietzsche; Nature, Teleology, Vital Force, Unconscious.

Cad. Nietzsche, Guarulhos/Porto Seguro, v.41, n.3, setembro-dezembro $2020 \mid 161$ 


\section{Referências}

BEISER, F. Late German Idealism. Trendelenburg and Lotze. Oxford: Oxford University Press, 2013.

BOWIE, A. "The philosophical significance of Schelling's conception of the unconscious". In: NICHOLLS, A. e LIEBSCHER, M. (ed.) Thinking the Unconscious. Nineteenth-Century German Thought. Cambridge University Press, 2010, pp. 57-86.

CAVALCANTI, A. H. Símbolo e Alegoria: a gênese da concepção de linguagem em Nietzsche. São Paulo/Rio de Janeiro: Annablume/Fapesp/DAAD, 2005.

CRAWFORD, C. The beginnings of Nietzsche's theory of language. Berlin. New York: Walter de Gruyter, 1988.

CRUZ, M. A. "Nietzsche and the Nineteenth-Century Debate on Teleology". In: LEMM, V. (ed.) Nietzsche and the Becoming of Life. New York: Fordham University Press, 2015.

DALLA VECCHIA, R. O(s) perspectivismo(s) de Nietzsche. Tese (Doutorado em Filosofia) - Universidade Estadual de Campinas, Campinas, 2014.

EMDEN, C. J. Nietzsche's Naturalism. Philosophy and the Life Sciences in the Nineteenth Century. Cambridge: Cambridge University Press, 2014.

GENTILI, C. “Kant's ,kindischer Anthropomorfismus'. Nietzsches Kritik der ,objektiven' Teleologie". In: Nietzsche-Studien, vol. 39, 2010, pp. 110-119.

GERRATANA, F. "Jetzt zieht mich das Allgemein-Menschliche an". Ein Streifzug durch Nietzsches Aufzeichnungen zu einer, Geschichte der litterarischen Studien". In: Borsche T.; Gerratana, F.; Venturelli, A. (ed.) Centauren-Geburten. Wissenschaft, Kunst und Philosophie beim jungen Nietzsche. Berlin. New York: Walter de Gruyter, 1994.

GÖDDE, G. Traditionslinien des „Unbewußten“. Schopenhauer - Nietzsche - Freud. Gießen: Psychosozial-Verlag, 2009. 
Natureza, vida e finalismo nas notas sobre a teleologia e sobre a origem da linguagem de Nietzsche (1868-69)

GÖDDE, G.; BUCHHOLZ, M. B. Unbewusstes. Gießen: Psychosozial-Verlag, 2011.

GOLDMANN, S. "Von der »Lebenskraft « zum »Unbewussten« - Stationen eines Konzeptwandels der Anthropologie". In: BUCHHOLZ, M. e GÖDDE, G. (ed.) Macht und Dynamik des Unbewussten. Auseinandersetzungen in Philosophie, Medizin und Psychoanalyse. 2. Auflage. Gießen: Psychosozial-Verlag, 2011, pp. 125-152.

hartmanN, E. v. Philosophie des Unbewußten. Versuch einer Weltanschauung. Berlin: Carl Duncker's Verlag, 1869.

KANT, I. Crítica da faculdade de julgar. Trad. Fernando Costa Mattos. Petrópoles: Editora Vozes, 2016.

LANGE, F. A. Geschichte des Materialismus und Kritik seiner Bedeutung in der Gegenwart. Iserlohn: J. Baedeker, 1866.

LARSON, J. L. "Vital Forces: Regulative Principles or Constitutive Agents? A Strategy in German Physiology, 1786-1802". In: Isis, vol. 70, n. 2, jun. 1979, pp. 235-249.

LENOIR, T. "The Göttingen School and the Development of Transcendental Naturphilosophie in the Romantic Era". In: Studies in the History of Biology, vol. 5, 1981, pp. 111-205.

LOPES, R. A. Ceticismo e vida contemplativa em Nietzsche. Tese (Doutorado em Filosofia) - Universidade Federal de Minas Gerais, Belo Horizonte, 2008.

. "O corpo como fio condutor: Notas a propósito de uma expressão". In: MARTON, S.; BRANCO, M. J. M.; CONSTÂNCIO, J. (ed.) Sujeito, décadence $e$ arte. Nietzsche e a modernidade. Lisboa: Tinta da China, 2014, p. 99-142.

MATTIOLI, W. O inconsciente no jovem Nietzsche: da intencionalidade das formas naturais à vida da linguagem. Tese (Doutorado em Filosofia) Universidade Federal de Minas Gerais, Belo Horizonte, 2016.

. "A questão da teleologia nos apontamentos do jovem Nietzsche: $Z u$ Schopenhauer e Zur Teleologie (1867-68)". Cadernos Nietzsche, vol. 39, n. 3, setembro/dezembro, 2018a, pp. 77-119. 
“ 'Dem Willen zum Leben ist das Leben gewif': vida e finalidade em Schopenhauer". In: Sofia, v. 7, n. 2, p. 201-225, jul./dez. 2018b.

NIETZSCHE, F. W. Sämtliche Werke. Kritische Studienausgabe (KSA). Herausgegeben von Giorgio Colli und Mazzino Montinari. 15 Bände. Berlin: Walter de Gruyter, 1999.

. Werke. Kritische Gesamtausgabe (KGW). Herausgegeben von Giorgio Colli und Mazzino Montinari. Berlin. New York: Walter de Gruyter, 1995.

Sämtliche Briefe. Kritische Gesamtausgabe (KGB). Herausgegeben von G. Colli und M. Montinari. 8 Bände. Berlin. New York: Walter de Gruyter, 1986.

. Frühe Schriften. (= BAW: 05 vols.). Hrsg. von Carl Koch und Karl Schlechta. München: C. H. Beck'sche Verlagsbuchhandlung (1933-1940), 1994.

REILL, P. H. Vitalizing Nature in the Enlightenment. Berkeley/Los Angeles/ London: University of California Press, 2005.

RICHARDS, R. J. The Romantic Conception of Life. Science and Philosophy in the Age of Goethe. Chicago: The University of Chicago Press, 2002.

SCHOPENHAUER, A. Parerga e Paralipomena. In: Sämtliche Werke. Hrsg. v. Paul Deussen. München: Piper Verlag, 1911-1926. (Werke auf CDROM: Schopenhauer im Kontext).

. O mundo como vontade e como representação. Tomo I. Trad. Jair Barboza. São Paulo: Editora Unesp, 2005.

. Sobre a vontade na natureza. Trad. Gabriel Valladão Silva. Porto Alegre: L\&PM, 2013.

. O mundo como vontade e como representação. Tomo II. Trad. Jair Barboza. São Paulo: Editora Unesp, 2015.

TEMP, D. "As anotações de Nietzsche sobre a teleologia". In: Dissertatio, v. 50, 2019, pp. 203-225. 
Natureza, vida e finalismo nas notas sobre a teleologia e sobre a origem da linguagem de Nietzsche (1868-69)

TOSCAnO, A. "The Method of Nature, the Crises of Critique. The Problem of Individuation in Nietzsche's 1867/1868 Notebooks". In: Pli: The Warwick Journal of Philosophy, vol. 11, 2001, pp. 36-61.

THÜRING, H. "Beiträge zur Quellenforschung”. In: Nietzsche-Studien, vol. 23, 1994, pp. 480-489.

VÖLMICKE, E. Das Unbewußte im Deutschen Idealismus. Würzburg: Königshausen \& Neumann, 2005.

Enviado: 21/07/2020

Aceito: 10/09/2020 